\title{
Reduced Order Modelling and Balancing Control of Bicycle Robot
}

A new result for balancing control of a bicycle robot (bicyrobo), employing reduced-order modelling of a pre-specified design controller structure in higher-order to derive into a reduced controller has been presented in this paper. The bicyrobo, which is an unstable system accompanying other causes of uncertainty such as un-model dynamics, parameter deviations, and external disruptions has been of great interests to researchers. The controllers in the literature reviews come up with the higher order controller (HOC), the overall system becomes complex from the perspective of analysis, synthesis, enhancement and also not easy to handle it's hardware implementation. Therefore, a reduced-order pre-specified controller is developed in this work. It is effective enough to tackle unpredictable dynamics. The reduced-order controller (ROC) design is based on model order reduction (MOR) method, which is a resutl of hybridization of balanced truncation (BT) and singular perturbation approximation (SPA) approach. The reduced model so obtained, which retains DC gain as well, has been named as balanced singular perturbation approximation (BSPA) approach. It is based upon the preservation of dominant modes (i.e. appropriate states) of the system as well as the removal of states having relatively less important distinguishing features. The strong demerit of the BT method is that, for reduced-order model (ROM), steady-state values or DC gain do not match with the actual system values. The BSPA has been enabled to account for this demerit. The method incorporates greater dominant requirements and contributes to a better approximation as compared to the existing methods. The results obtained by applying proposed controller, are compared with those of the controllers previously designed and published for the same type of work. Comparatively, the proposed controller has been shown to have better performance as HOC. The performance of HOC and ROC is also examined with perturbed bicyrobo in terms of time-domain analysis and performance indices error.

Keywords: Bicyrobo, MOR, BSPA, Higher-order controller, Reducedorder modelling.

\section{INTRODUCTION}

The main challenge in modern robotics is to produce behaviour that can be adapted in real time. We need robots that are adaptive and learning to deal with dynamic environments such as humans and animals. Robots perform various tasks that improve quality and ease of transport. Mobile robots, underwater and flying robots, robotic networks, surgical robots with high operational efficiency are playing an increasing role in society [1-4]. A bicycle robot is a good means of transportation because of its advantageous attributes such as being light in weight and environmentally friendly. The bicyrobo has inherently nonlinear system dynamics and is naturally unstable as well, which makes

Received: September 2020, Accepted: August 2021 Correspondence to: Santosh Kumar Suman Department of Electrical Engineering, Madan Mohan Malaviya University of Technology, Gorakhpur, India E-mail: sksumanee@gmail.com

doi: $10.5937 /$ fme2104919K

(C) Faculty of Mechanical Engineering, Belgrade. All rights reserved it difficult to control. As a result, it brings exciting challenges to the control engineering community. Several researchers have been conducting research on various mechatronic systems for dyna-mically balancing and manoeuvre bicycles.

Bicycles have been used to help people move around for leisure, recreation, and transportation since the $1800 \mathrm{~s}$. Wheeled transportation is the cheapest way to get around. Between the $19^{\text {th }}$ and $20^{\text {th }}$ centuries, the bicycle was continually improved, which led to the modern wheeled transport what we have today [5]. The history of bicycles can be found in the proceedings of the international conference on cycling history, which is held every year since 1990 [6]. Robust control techniques have been applied to control and move these two-wheel mobile robots that are always unstable with nonlinear behaviour, are influenced by external disturbances also. The work focuses on the balancing control of the bicyrobo. The efficiency of HOC and ROC is also evaluated with perturbed bicyrobo. The key goal of the bicycle is to move properly with and without 
load, to move forward or backward, and to turn left or right without breaking. Bicycle is a big control balancing issue, an unstable system associated with different sources of uncertainty due to unmodeled dynamics, parameter variations and outside disturbances [6]. The concept of a self-balancing bicycle or a bicyrobo is, therefore, an important research subject. The murata boy robot which was firstly created in Japan, 2005 is a typical example of a bicyrobo. There are many solutions to controlling bicycle robots [7], such as using flywheels [8], steering control [9], balancing control [10,11], stabilization and motion control [12] or moving the centre of gravity [13]. There are several practical methods to take from this class. In this we describe some recommendations for balancing the flywheel. Among these options, flywheel balancing, which utilises a spinning wheel as a gyroscopic stabiliser, a good option as the response time is short and the system is stable even when stationary, as shown in Table 1. The search in the literature identified numerous investigators who have designed better controllers for bicyrobo. In this study, the number of linear controllers, such as $\mathrm{H}_{2}, \mathrm{H}_{\infty}$ came into the picture due to their robustness. They are more robust than the other controllers available in the literature review because they are less sensitive to external disturbances and errors. A robust controller for a system with varying uncertainties is being designed by Khargonekar et al., (1991). A robust technique in which composite $\mathrm{H}_{2} / \mathrm{H}_{\infty}$ control is used for such type of systems as suggested in [14]. The controller design is oriented toward designing controllers that exhibit robust stability as well as superior performance, for instance, small tracking error, lower control energy, etc. Despite its complex design procedures, advanced control methods like PID (proportional integral derivative) and lead-lag are rarely utilised like the mixed $\mathrm{H}_{2} / \mathrm{H}_{\infty}$ control due to the requirement for advanced design procedures and resulting in advanced controllers. The controllers are of high order and achieve the same results as augmented plants through the application of a Riccati equation approach [15]. Several investigators have used nature-inspired search algorithms to design robust controllers [16-18].

The HOC architecture can contribute to several drawbacks as we run robot balanced control prog-rammes due to dynamic software that increases the running time, the slow response speed of the control system without a reasonable solution to the controller's realtime specifications and the stability of the balanced system. In order to improve the efficiency of this controller, the ROC should be set up to simplify the programme code, reduce the computational time, increase the response speed, but still comply with the system's reliability requirements [19]. The complex design process and HOC achievements are the greatest disadvantages for these controllers. To contribute, several researchers in the literature have recently proposed a large number of order reduction techniques [20-25].Therefore, a ROC is needed to preserve all the appropriate characteristics of the HOC. ROC may lead to a reduction in computing effort, cost reduction and simulation time.
The proposed article provides a methodology as a new result to design pre-specified structure [16] for balancing control of bicyrobo using reduced order modelling, which is based upon a hybridization of BT and SPA called BSPA approach [26]. Is is based on the concept of preserving the essential parameter and characteristics of the HOC in the ROC. The proposed method is based upon this preservation of dominant modes or states of the system as well as the removal of relatively less important distinguishing feature.

The reduced controllers developed by the proposed approach are compared to HOCs and other ROCs for reported research in terms of performance index error criteria. Based on the effect disturbance and uncertainty generated by the multiple sources of instability related to un-modelled dynamics, it is difficult to suppress parameter variations using the conventional and higher order controller methodology. The $1^{\text {st }}, 2^{\text {nd }}, 3^{\text {rd }}, 4^{\text {th }}$ and $5^{\text {th }}$ order controllers designed by the proposed method are compared with the higher order controller and other reduced order controllers available in the literature review, on the basis of the time domain specification and various performance indices. The performance of the bicycle robot is also analysed with higher and lower order controllers in the presence of uncertainty. The proposed 3rd order controller has been found to have excellent and superior performance compared to other controllers.

This paper is divided into five sections. Section 1 includes an overview and a detailed summary of the literature review for control strategies of bicycle robot studies. The mathematical modelling of the bicycle robot is defined in section 2. The proposed methodology for reduced order modelling is described out here in the Sect. 3. Computational analysis for HOC and implementation of ROC of bicyrobo using the proposed methodology is given in Sect. 4, followed by bicycle robot's controller taken from the literature and compared with, for the validity of the proposed method. Finally, section 5 points out the premise and the future scope of the work discussed.

\section{MATHEMATICAL MODELLING OF THE SYSTEM}

We describe generalized $n^{\text {th }}$ order LTI continuous-time systems in a state-space model form is given by

$$
\left\{\begin{array}{l}
\frac{x(t)}{d t}=A_{o} x(t)+B_{o} u(t) \\
y(t)=C_{o} x(t)+D_{o} u(t)
\end{array} \Leftrightarrow \sum:=\left(\begin{array}{c:c}
A_{o} & B_{o} \\
\hline C_{o} & D_{o}
\end{array}\right)\right.
$$

where suffix 'o' is denoted for the actual system and an n-dimensional state vector $x \in \mathbb{R}^{n}, u \in \mathbb{R}^{p}$ are the inputs of the system and, $y \in \mathbb{R}^{q}$ of the system outputs. The state-space model matrices have dimensions $A_{o} \in \mathbb{R}^{n \times n}, B_{o} \in \mathbb{R}^{n \times p}, C_{o} \in \mathbb{R}^{q \times n}, D_{o} \in \mathbb{R}^{q \times m} \cdot \mathrm{p}=$ $\mathrm{q}=1$, the actual system is referred to as the SISO system, otherwise, it will be called the multidimensional system. In the case of multi-dimensional, it is assumed that the number of inputs and outputs is much lower than the number of states., i.e., $p, q<<n$. 
Dynamical system refer to (1) is called asymptotically stable when all the finite values of the matrix write are specified in [27-31] The frequency response is another important measure to study the characteristics of the LTI system. To determine the frequency response, the system referring to (1) appears to be applying the transformation of Laplace is given as

$$
\begin{aligned}
& \qquad \mathrm{Y}_{r}(\mathrm{~s})=\mathrm{G}_{r}(\mathrm{~s}) \mathrm{U}(\mathrm{s}) \\
& \text { where } G_{0}(s)=C_{0}\left[s I_{n}-A_{0}\right]^{-1} B_{0}+D_{0} . \\
& \qquad G_{p}(s)=\frac{N_{o}(s)}{D_{o}(s)}=\frac{n_{0}+n_{1} s+n_{2} s^{2}+\cdots n_{m-1} s^{m-1}}{d_{0}+d_{1} s+d_{2} s^{2}+\cdots+d_{n} s^{n}}
\end{aligned}
$$

where $n_{i}, d_{i}$ are scalar constants of the $\mathrm{n}$ dimensional.

\begin{tabular}{|c|c|c|}
\hline 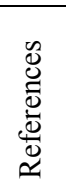 & Objectives & $\begin{array}{l}\text { Methods to tackle a } \\
\text { problem }\end{array}$ \\
\hline [13] & Self-stabilizing strategy & Sliding Patch Theory \\
\hline [9] & $\begin{array}{l}\text { Bicycle steering based on } \\
\text { acceleration control }\end{array}$ & $\begin{array}{l}\text { Disturbance Observer } \\
\text { design Setting gain } \\
\text { values }\end{array}$ \\
\hline$[7]$ & $\begin{array}{l}\text { Dynamic stabilization and } \\
\text { control moment gyroscope }\end{array}$ & SMC \\
\hline$[8]$ & $\begin{array}{l}\text { control of autonomous } \\
\text { motion }\end{array}$ & $\begin{array}{l}\text { Gyroscopic } \\
\text { Stabilisation, PID } \\
\text { controller }\end{array}$ \\
\hline [32] & $\begin{array}{l}\text { Dynamic compensation and } \\
\text { balancing control }\end{array}$ & PD controller \\
\hline [33] & $\begin{array}{l}\text { Balancing control with } \\
\text { uncertain COG }\end{array}$ & LQR method \\
\hline [16] & Balancing control & PSO \\
\hline [11] & $\begin{array}{l}\text { Self-balance using steering } \\
\text { control }\end{array}$ & $\begin{array}{l}\text { PID controller in } \\
\text { python, raspberry pi }\end{array}$ \\
\hline [34] & $\begin{array}{l}\text { Rider control while steering } \\
\text { and stabilizing }\end{array}$ & $\begin{array}{l}\text { Linear feedback } \\
\text { control }\end{array}$ \\
\hline [35] & Stabilization control & CADO \\
\hline [36] & $\begin{array}{l}\text { Attitude control by steering } \\
\text { angle and variable COG } \\
\text { control }\end{array}$ & PD control \\
\hline$[6]$ & $\begin{array}{l}\text { Control moment gyroscope } \\
\text { (CMG) for balancing }\end{array}$ & PD controller \\
\hline [37] & Balancing control & $\begin{array}{l}\text { Pole placement } \\
\text { technique }\end{array}$ \\
\hline [38] & Trajectory control & LQR method \\
\hline [39] & Self-balancing control & Feedback control \\
\hline [17] & Balancing control & $\begin{array}{l}\text { H } \infty \text { loop shaping } \\
\text { control, PSO }\end{array}$ \\
\hline [40] & Self-balancing control & $\begin{array}{l}\text { Optimization-based } \\
\text { PID controller }\end{array}$ \\
\hline [19] & Balancing control & $\begin{array}{l}\text { MOR based on Schur } \\
\text { analysis }\end{array}$ \\
\hline [20] & Balancing control & ROC using CSA \\
\hline
\end{tabular}

Table 1: A literature summary of control strategies for bicyrobo

\subsection{Modelling of a Bicyrobo}

The bicyrobo was developed as a platform for eva-luating the effectiveness of the advanced control algorithm and strategies (Bui et al., 2008) study at the Mechatronics Laboratory, the Asian Institute of Technology (AIT),
Klong Luang, Pathum Thani 12120, Thailand [16]. This paper considers the typical example of the model of a bicyrobo. The system is adapted to the normal size of a bicycle. Figure 1 shows a picture of the bicyrobo, consisting of two wheels mounted on a different axis.

The aim of this bicyrobo is to move properly with and without load, to move forward or backward, and to turn left or right without falling. Bicyrobo is a major problem in control balancing, an unstable system and nonlinear associated with various causes of uncertainty due to unmodeled dynamics, parameter variations and external disturbances. As a result, many authors have suggested a variety of control strategies to address the problem of perturbed bicyrobo. Flywheel balancing is used among all strategies, mainly to equalise the torque caused by the gravity of the robot's flywheel. The bicyrobo of dynamics model is derived by Lagrange equation as follows:

$$
\frac{d}{d t}\left\{\frac{\partial E_{k}}{\partial \dot{p}_{i}}\right\}-\frac{\partial E_{k}}{\partial p_{i}}+\frac{\partial E_{p}}{\partial p_{i}}=P_{i}
$$

where $E_{k}$ is the total kinetic energy of the system, $E_{p}$ is the total potential energy of the system, $P_{i}$ is external forces, $p_{i}$ is generalized coordinate. $E_{k}$ and $E_{p}$ are computed and defined by the following equations.

$$
\begin{gathered}
E_{p}=m_{x} g h_{x} \cos \theta+m_{y} g h_{y} \cos \theta \\
E_{k}=\frac{1}{2} m_{x}\left(\dot{\theta}^{2} h_{x}^{2}\right)+\frac{1}{2} m_{y}\left(\dot{\theta}^{2} h_{y}^{2}\right)+\frac{1}{2} I_{x} \dot{\theta}^{2} \\
+\frac{1}{2}\left[I_{y} \dot{\delta}^{2}+I_{z}(\dot{\theta} \sin \delta)^{2}+I_{y}(\dot{\theta} \cos \delta)^{2}\right]
\end{gathered}
$$

where $m_{x}$ and $m_{y}$ are both mass of bicycle and flywheel, $I_{z}$ is flywheel polar moment of inertia (MI) and $I_{x}$ is flywheel radial moment of inertia respectively. $I_{y}$ is bicycle moment of inertia.

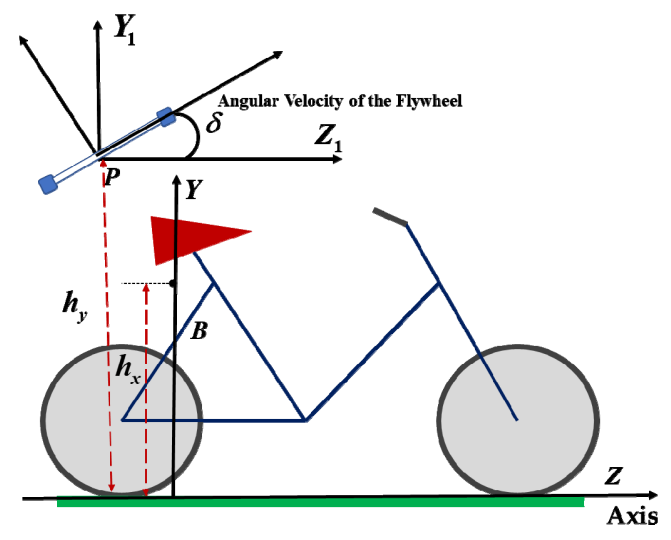

Figure 1. Reference Diagram of Bicyrobo (side view)

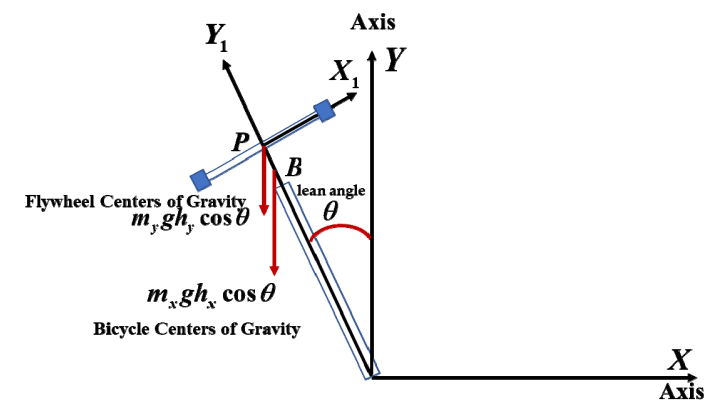

Figure 2. Reference diagram of bicyrobo (front view) 
According to the above, Figure 1 and Figure 2, in a side view and back view, display the bicyrobo coordinate system and parameters, where $\theta$ is the lean angle of bicyrobo along the Z-axis and also it is the angular velocity of the bicyrobo along with this axis, $\delta$ is the angle of the flywheel along with $Z_{1}$ axis, also it is the angular velocity of the flywheel along with $X_{1}$ axis, $h_{x}$ is the height of the COG of a bicycle robot, whereas $h_{y}$ is the height of flywheel COG, respectively.

For $p_{i}=\theta$ use refer to the above equation ( 5 to 7 ). The equation is derived below.

$$
\begin{aligned}
& \ddot{\theta}\left[m_{x} h_{x}^{2}+m_{y} h_{y}^{2}+I_{x}+I_{z} \sin ^{2} \delta+I_{y} \cos ^{2} \delta\right] \\
& +2 \sin \delta \cos \delta\left(I_{z}-I_{m}\right) \dot{\theta} \dot{\delta}-g\left(m_{x} h_{x}+m_{y} h_{y}\right) \sin \theta=I_{z} \omega \dot{\delta} \cos \delta
\end{aligned}
$$

According to the same way as referred to the above equation, for $p_{i}=\delta$ the following equation is computed by

$$
\ddot{\delta} I_{y}-\dot{\theta}^{2}\left(I_{z}-I_{y}\right) \sin \delta \cos \delta=\tau_{m}-I_{z} \omega \dot{\theta} \cos \delta-\gamma_{m} \dot{\delta}
$$

where $\tau_{m}$ is a torque established by DC motor and $\gamma_{m}$ is viscosity coefficient of DC motor.

Table 2: Value of the bicyrobo Parameters

\begin{tabular}{lcc}
\hline \multicolumn{1}{c}{ Name of Parameters } & Symbols & Value in SI units \\
\hline Gravity constant & $g$ & $9.81 \mathrm{~m} / \mathrm{s}^{2}$ \\
Bicyrobo MI & $I_{x}$ & $27.584 \mathrm{kgm}^{2}$ \\
Flywheel radial MI & $I_{y}$ & $0.112304 \mathrm{kgm}^{2}$ \\
Flywheel polar MI & $I_{z}$ & $0.2159260 \mathrm{kgm}^{2}$ \\
Mass of flywheel & $m_{y}$ & $43.10 \mathrm{~kg}$ \\
Mass of Bicyrobo & $m_{x}$ & $8.1 \mathrm{~kg}$ \\
$\begin{array}{l}\text { Bicyrobo Heights (COG) } \\
\text { Height of flywheel (COG) }\end{array}$ & $h_{x}$ & $0.860 \mathrm{~m}$ \\
$\begin{array}{l}\text { Viscosity coefficient of } \\
\text { DC motor }\end{array}$ & $h_{y}$ & $0.80 \mathrm{~m}$ \\
$\begin{array}{l}\text { Back emf constants of DC } \\
\text { motor }\end{array}$ & $\gamma_{m}$ & $0.000253 \mathrm{kgm} / \mathrm{s}$ \\
$\begin{array}{l}\text { Armature resistant of DC } \\
\text { motor }\end{array}$ & $R$ & $0.1184 \mathrm{rad} / \mathrm{s}$ \\
$\begin{array}{l}\text { The inductance of DC } \\
\text { motor }\end{array}$ & $L$ & $0.41 \Omega$ \\
$\begin{array}{l}\text { Flywheel speed } \\
\text { Torque constants of DC } \\
\text { motor }\end{array}$ & $\omega$ & $0.0006 \mathrm{H}$ \\
\hline
\end{tabular}

The dynamics of the DC motor with a 5:1 ratio is supposed to be for the chain transmission system as follows the equations.

$$
\begin{aligned}
& \tau_{m}=5 T_{m} i \\
& Y=L \frac{d i}{d t}+R i+E_{b} \delta
\end{aligned}
$$

where $T_{m}$ is the torque of DC motor and $E_{b}$ is known as back EMF or counter EMF $\left(E_{b}\right)$ of DC motor. $R$ and $L$ are armature resistant and inductance of the DC motor correspondingly. The $\tau_{m}$ is the torque produced by the motor.

By substitution of equation number (10) into equation number (9), and linearization (8) and (9) around the equilibrium point, the following equations are obtained.

$$
\begin{aligned}
& \ddot{\theta}\left[m_{x} h_{x}^{2}+m_{y} h_{y}^{2}+I_{x}+I_{y}\right]-g\left(m_{x} h_{x}+m_{y} h_{y}\right) \theta-I_{z} \omega \dot{\delta}=0 \\
& \ddot{\delta} I_{y}+I_{z} \omega \dot{\theta}+\gamma_{m} \dot{\delta}-5 T_{m} i=0
\end{aligned}
$$

Let us consider that $x=[\theta \dot{\theta} \dot{\delta} i]^{\prime}, y=\theta$ and $u=Y$, on combining the equations. (11) to (13), the state-space model of the system is represented according to equation higher-dimensional system (1) as follows-

$$
\begin{gathered}
A=\left[\begin{array}{cccc}
0 & 1 & 0 & 0 \\
\frac{g\left(m_{x} h_{x}+m_{y} h_{y}\right)}{\left(m_{x} h_{x}^{2}+m_{y} h_{y}^{2}+I_{x}+I_{y}\right)} & 0 & \frac{I_{z} \omega}{m_{x} h_{x}^{2}+m_{y} h_{y}^{2}+I_{x}+I_{y}} & 0 \\
0 & -\frac{I_{z} \omega}{I_{y}} & -\frac{\gamma_{m}}{I_{y}} & \frac{5 T_{m}}{I_{y}} \\
0 & 0 & -\frac{E_{b}}{L} & -\frac{R}{L}
\end{array}\right], \\
B=\left[\begin{array}{llll}
0 & 0 & 0 & \frac{1}{L}
\end{array}\right]^{T}, C=\left[\begin{array}{llll}
1 & 0 & 0 & 0
\end{array}\right], D=0
\end{gathered}
$$

\section{PROPOSED METHODOLOGY FOR REDUCED ORDER MODELLING}

MOR aims to replicate a significantly reduced dimensional system with the same characteristics for a higher-dimensional system, refer to (1). This has approximated the system itself in some way and preserves the key parameters of a higher dimension system. Such a solution is the higher order solution for the same input form as closely as possible.

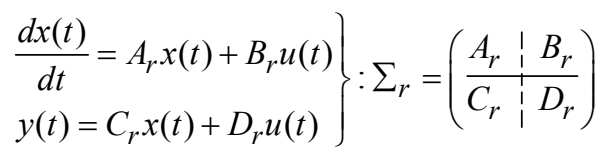

where $r \ll n$ so that the transfer function of the reduced -dimensional system [41].

Let, $n=$ higher -dimensional system, $\mathrm{k}=$ minimal order of the higher -dimensional system (for the nonminimal higher-order system; for a minimal system $k=$ $n, r^{\text {th }}=$ reduced-order model of higher -dimensional system.

Analogous to (2), applying the Laplace transformations to the system (15) we get

$$
Y_{r}(s)=G_{r}(s) U(s)
$$

where

$$
G_{r}(s)=R_{r}(s)=C_{r}\left(s I_{n_{r}}-A_{r}\right)^{-1} B_{r}+D_{r}
$$

The $\operatorname{Gr}(s)$ is a ROM, and it is in the form of the polynomial coefficient is given as

$$
G_{r}(s)=\frac{\hat{N}_{r}(s)}{\hat{D}_{r}(s)}=\frac{\hat{n}_{0}+\hat{n}_{1} s+\hat{n}_{2} s^{2}+\cdots \hat{n}_{m-1} s^{m-1}}{\hat{d}_{0}+\hat{d}_{1} s+\hat{d}_{2} s^{2}+\cdots+\hat{d}_{n} s^{n}}
$$

\subsection{Balanced Truncation Method}

We can find a good incentive for a BT initially suggested [29]. BT is one of the most widely used MOR methods in the frequency domain. A reduced model is to be obtained by removing those states which are the least or weakly 
controllable and observable measured in accordance with the size of the Hankel singular value (HSV). HSV, provide a measure of energy for each state within the control theory system structure. They are the basis for a balanced reduction of the system, which preserves high energy levels while discarding low-energy states. The reduced model retains significant features of the original systems $[27,31,42-45]$.The pri-mary concept is that the singular values of cont-rollability gramians relate to the amount of energy that must be put into the system in order to move the app-ropriate states. The reduced model is achieved in this approach by eliminating the least controllable and least observable states of the balanced system. The original system has been balanced by using a transformation of similarity $[46,47]$.

A stable, original system $G_{0}(s)$ is called balanced if the solution both gramians such as controllability $\left(P_{c}\right)$ and observability $\left(P_{0}\right)$ to the following equation,

$$
\begin{gathered}
A_{0} P_{C}+P_{C} A_{0}{ }^{T}+B_{0} B_{0}{ }^{T}=0 \\
A_{0}{ }^{T} P_{0}+P_{0} A_{0}+C_{0}{ }^{T} C_{0}=0
\end{gathered}
$$

are such that $P_{0}=P_{0}=\operatorname{dia}\left(\sigma_{1}, \sigma_{2}, \ldots, \sigma_{n}\right): \Sigma$ with $\sigma_{1} \geq \sigma_{2} \geq$ $\ldots \geq \sigma_{\mathrm{n}} \geq 0$ and $P_{c}$ and $P_{0}$ are called controllability gramian and observability gramian, respectively. when the system is balanced, both gramians are diagonal and equal $\sigma_{i}, i=1, \cdots, n$, is the $i^{\text {th }}$.

The Steps of MOR algorithm using BT Method are given below.

Table 3: MOR Algorithm Using Balanced Truncation Method

Input: $\left(A_{0}, B_{0}, C_{0}, D_{0}\right)$ : Higher -dimensional system

Output: Proposed ROM $\left(A_{r}, B_{r}, C_{r}, D_{r}\right)$

Step 1. Calculate the factor $X=R^{R T}$ and $Y=L L^{T}$

Step 2. Calculate the singular value decomposition (SVD)

$$
R^{T} \in L=U \sum V^{T}=\left[U_{1} U_{2}\right]\left[\begin{array}{ll}
\Sigma_{1} & \\
& \Sigma_{2}
\end{array}\right]\left[\begin{array}{l}
V_{1}^{T} \\
V_{2}^{T}
\end{array}\right]
$$

With $\Sigma_{1}=\operatorname{diag}\left(\xi_{1}, \ldots, \xi_{l}\right), \sum_{2}=\operatorname{diag}\left(\xi_{l+1}, \ldots, \xi_{n}\right)$.

Step 3. Construct $V=L V_{1} \Sigma_{1}^{-\frac{1}{2}}, T=R U_{1} \Sigma_{1}^{-\frac{1}{2}}$.

Step 4. Compute the ROM

$\left(A_{r}, B_{r}, C_{r}, D_{r}\right)=\left(T^{T} A_{0}{ }^{T}, T^{T}, B_{0}, C_{0}, T, D_{0}\right)$ : lower -dimensional system

Properties

- $\quad\left(A_{r}, B_{r}, C_{r}, D_{r}\right)$ is asymptotically stable

- Error bound:

$$
\left\|R_{r}(s)-G(s)\right\|_{\mathrm{H}_{\infty}} \leq 2\left(\xi_{r+1}+\ldots+\xi_{n}\right) .
$$

- Must solve the large -scale Lyapunov equations.

Unlike getting the direct $r^{\text {th }}$ order BT model [47], first, we eliminate to obtain the minimal order ( $k^{\text {th }}$ order) balanced truncated model of higher -dimensional system (G(s)) using the truncation matrices is called Transformation matrices (T). Now the system is balanced, which is partitioned as $[28,48,49]$.

$$
\hat{G}(s)=\left[\begin{array}{c:c}
T^{-1} A_{o} T & T^{-1} B_{o} \\
\hline C_{o} T & D_{o}
\end{array}\right]=\left[\begin{array}{c:c}
\hat{A} & \hat{B} \\
\hline \hat{C} & \hat{D}
\end{array}\right]
$$

where $A \in \mathbb{R}^{n \times n}$ and $\hat{A} \in \mathbb{R}^{k \times k} \hat{G}(s)$ is balanced system for higher -dimensional system.

Here, $k<n$ is for non-minimal system while $k=n$ is for higher -dimensional system (minimal system). $\hat{G}(s)$ balanced system (21) will be the ( $k^{\text {th }}$ order) balanced realized model for non-minimal systems, while in case of the minimal system it will be the higher dimensional system ( $n^{\text {th }}$ order) balanced realization model. Thus, up to this step, the algorithm works selfminimal realisation method.

Select the reduced model number, $r(t<k<n)$ of the system based on higher magnitudes of Hankel singular values [50]. Balanced which is partitioned as strong subsystem and weak subsystem [44].

$$
\begin{aligned}
& =\underbrace{\left[\begin{array}{cc}
A_{11} & B_{1} \\
C_{1} & D_{r}
\end{array}\right]}_{\text {Strong }}+\underbrace{\left[\begin{array}{cc}
A_{22} & B_{2} \\
C_{2} & 0
\end{array}\right] \Leftrightarrow \sum:\left[\begin{array}{cc}
\Sigma_{1} & 0 \\
0 & \Sigma_{2}
\end{array}\right]}_{\text {Weak }} \\
& =\underbrace{\text { Strong Subsyustem }}_{\text {(to be retained) }}+\underbrace{\text { Weak Subsystem }}_{\text {(to be retained) }} \Leftrightarrow \sum
\end{aligned}
$$

Since partition, the balanced system $(\hat{A}, \hat{B}, \hat{C}, \hat{D})$ and the gramian $\Sigma$ conformally given as

$$
\left.\begin{array}{l}
\hat{A}=\left[\begin{array}{ll}
A_{11} & A_{12} \\
A_{21} & A_{22}
\end{array}\right], \hat{B}=\left[\begin{array}{l}
B_{1} \\
B_{2}
\end{array}\right], \\
\hat{C}=\left[\begin{array}{ll}
C_{1} & C_{2}
\end{array}\right], \hat{D}=D
\end{array}\right\}
$$

where $\mathrm{A}_{11}$ and $\Sigma_{1}$ are lower-order matrix, it is part of a strong subsystem which is also $(\mathrm{r}<\mathrm{n})$. The subsystem $\left(A_{11}, B_{1}, C_{1}\right)$ must be a good approximation of the balanced system $\hat{G}(s)$ if $\sigma_{r} \gg \sigma_{r+1}$ proposed by the B C. Moore, 1981 [29]. We call this $\mathrm{r}^{\text {th }}$ ordering system a direct reduction (DR) or direct truncation (DT) approximation of the balanced system. Several nicely-recognized results that are relating to the approximation is available in the [51].

Therefore, stronger subsystem, the $r^{\text {th }}$ order balanced truncation model is,

$$
G_{r_{-} B T}(s)=\left[\begin{array}{l|l}
A_{11} & B_{1} \\
\hline C_{1} & D
\end{array}\right]
$$

where $A_{11} \mathbb{R}^{r \times r}$ and $\sum_{1}$ are reduced matrix $(r<n)$.

The above BT model does not give the guarantee to preserve the DC gain of the actual or higher system [52]. refer to (12) has been achieved as a minimally realized model comprising strong and weakly subsystems. Thus, the SPA can be extended effortlessly to the (12) subsystems. Reduced (r) balanced states are preser-ved in the BT model, which are entirely controllable and observable such that balanced states are maintained and the remaining weakly controllable and/or measurable states are truncated. The SPA [47] is used to preserve the DC gain value of the original system in the model $[50,52,53]$. The concerned researcher may referee to [54] for more indications of the method. 


\subsection{Hybrid Method for Approximation}

In numerous engineering, the system's steady-state gain, usually referred to as DC gain (the system gains at an infinitive time, equivalent to $\mathrm{G}_{0}(0)$, plays an important role in evaluating system performance. It is, therefore, better to maintain the DC gain in the ROM, i.e., $\mathrm{G}_{\mathrm{r}}(0)=$ $\mathrm{G}_{0}(0)$, the balanced truncation method introduced in the above subsection does not keep the DC gain unchanged [55]. Suppose that $\left(A_{0}, B_{0}, C_{0}, D_{0}\right)$ is compatible with minimal and balanced truncation of the stable $\mathrm{G}_{0}(0)$ and partitioned system as in the previous subsection. It can be demonstrated that stable is $\mathrm{A}_{22}$.

In this section, we address the order reduction procedure for higher-dimensional systems resulting in a hybrid approach using BT and a balanced SPA. In the BT method, all balanced systems are divided into two parts as a slow and fast mode by defining the lower Hankel singular values (HSV) as a fast mode, while the others are defined as a slow mode. First, the derivative of all states equal to zero in fast mode can be achieved by defining a reduced system. The main objective of maintaining the structure of the ROM is to preserve the dominant frequencies of the original system, in the reduced system, therefore, to preserve dominant dynamic modes [26].

The resulting reduced system which preserves the DC gain and steady state values is called BSPA approach [26] and is given $[53,56]$.

Now, the final system $(\bar{A}, \bar{B}, \bar{C}, \bar{D})$ conformally as in (26).

$$
\begin{gathered}
\bar{G}(s)=\left[\begin{array}{c:c}
\bar{A} & \bar{B} \\
\overline{\bar{C}} & \bar{D}
\end{array}\right]: \sum_{r}=\left[\begin{array}{ll}
\mathrm{A}_{\mathrm{r}} & \mathrm{B}_{\mathrm{r}} \\
\mathrm{C}_{\mathrm{r}} & \mathrm{D}_{\mathrm{r}}
\end{array}\right] \\
\Sigma_{r}=\underbrace{\left[\begin{array}{c:c}
A_{11}-A_{12} A_{22}^{-1} A_{21} & B_{1}-A_{12} A_{22}^{-1} B_{2} \\
\hdashline C_{1}-C_{2} A_{22}^{-1} A_{21} & D_{o}-C_{2} A_{22}^{-1} B_{2}
\end{array}\right]}_{\text {Balanced } S P A}
\end{gathered}
$$

The bicyrobo tests to demonstrate the method will be discussed in the preceding section and successfully validate the proposed method to balancing control by reduced controller.

Also, the accuracy and performance of the proposed method is measured by calculating indices error, which is commonly used as an integral square error (ISE), integral absolute error (IAE) and integral time-weighted absolute error (ITAE) to validate the output of the system. A comparison of the response has been done based on the unit step response. The performance of ROM obtained is also compared based on measures by calculating the performance indices, the accurateness of the proposed method which is index error between the transient sec-tions of the actual system and the ROM. performance indices error refer by [25,57-59] as discussed by the following equation

$$
\begin{aligned}
I S E & =\int_{0}^{\infty}\left[y_{1}(t)-y_{2}(t)\right]^{2} d t . \\
I A E & =\int_{0}^{\infty}\left|y_{1}(t)-y_{2}(t)\right| d t .
\end{aligned}
$$

$$
\text { ITAE }=\int_{0}^{\infty} t\left|y_{1}(t)-y_{2}(t)\right| d t .
$$

where $y_{1}(t)$ and $y_{2}(t)$ are the outputs of the actual system and ROM [59]-[64].

\section{COMPUTATIONAL ANALYSIS FOR HIGHER- ORDER CONTROLLER OF BICYROBO}

The values of the parameters of autonomous bicyrobo are identified as shown in Table 2. By substituting these values into state space model equation (14), the balancing system of bicyrobo is representation in the form of a nominal transfer function described as $T(S)=\frac{\theta(s)}{Y(s)}$.

$$
T(s)=\frac{4887}{\mathrm{~s}^{4}+683.30 \mathrm{~s}^{3}+1208.00 \mathrm{~s}^{2}+109700.00 s-6949.00}
$$

where $\theta(s)$ is the bicyrobo output lean angle and $Y(s)$ is the DC motor input voltage controlling the flywheel control axis. Suppose the bicyrobo system is affected by multivariate uncertainties and external disturbance, followed by cases for bicyrobo perturbed.

Case-1: Let the load be added with a further $10 \mathrm{~kg}$, and the flywheel speed is decreased to $147 \mathrm{rad} / \mathrm{s}$. Therefore, the bicyrobo perturbed model becomes the transfer function represented as the following.

$$
\hat{T}(s)=\frac{3784}{\mathrm{~s}^{4}+683.30 \mathrm{~s}^{3}+1162.00 \mathrm{~s}^{2}+78290.00 \mathrm{~s}-6857.00}
$$

Case -2: As for an additional $10 \mathrm{~kg}$, the additional load is applied again, and the speed of the flywheel is increased to $167 \mathrm{rad} / \mathrm{s}$. And the bicyrobo perturbed model is described as the following transfer function.

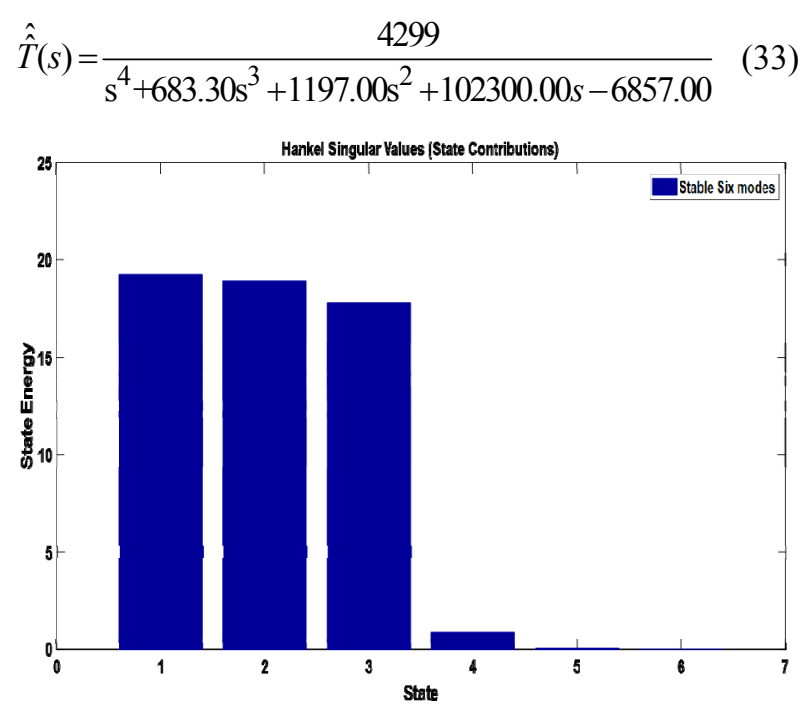

Figure 3. Hankel singular values plot of higher-order controller

Design of the controller for balancing control of bicyrobo system under $\mathrm{H}$-infinity full sustainable control procedure and strategies is developed by (Bui et al.,2008) [16,17] and the H-infinity $(\mathrm{H} \infty)$ controller is designed as follows 


$$
\begin{gathered}
1275 \mathrm{~s}^{5}+8.695 e 05 \mathrm{~s}^{4}+5.151 e 05 \mathrm{~s}^{3} \\
T_{C}(s)=\frac{+1.359 e 08 \mathrm{~s}^{2}+2.435 e 07 \mathrm{~s}+1.091 \mathrm{e} 06}{\mathrm{~s}^{6}+715.7 \mathrm{~s}^{5}+2.355 e 04 \mathrm{~s}^{4}+2.789 e 05 \mathrm{~s}^{3}} \\
+3.802 e 06 \mathrm{~s}^{2}+6.519 e 05 \mathrm{~s}+2.872 \mathrm{e} 04
\end{gathered}
$$

Hankel singular values of the original system are expressed as $\sigma$ is given by

$\sigma=[19.2747,18.9796,17.8203,0.9214,0.0432,0.0002]$

Through control theory, eigenvalues are classified as system stability, while HSV defines the "energy" of each state in the system. Retaining a larger energy state of the system retains much of its characteristics in terms of stability, frequency, and time response. The model reduction strategies presented are all based on the system's HSV. We can achieve a ROM that preserves much of the appearance of the system. The HSV bar chart diagram of the higher order controller is shown in Figure 3 and from the matrix refer to Eq. (35), the singular value of the controller has been also calculated. it is observed that $\sigma_{3}>\sigma_{4}$. The first-third, HSVs are important here, and the singular values fall very rapidly to the fourth value and are insignificant in the process of reduction. As a result, the order of reduction has been chosen as a third order.

The design and simulation of controllers is a complex task for a large system. This infinity controller $\left(H_{\infty}\right)$ is in sixth order. This higher-order controller is therefore practically difficult to implement. Due to the complex program that increases the processing time, the slow response rate of the control system is slow, without a good response to the controller's real-time requirements and the stability of the balanced system. As the order of the system increases, the complexity and cost of the design of the controller increase simultaneously.
Thus, this difficulty can be resolved if a "good" approximate reduced system is available for the original large-scale model and the design of the controller is carried out using a reduced model to make the program code easier, reduce the processing time, increase the response speed of the controller. In the case of a largescale system, for the design of feedback controllers, an enormous number of sensors is needed to detect the state variables of the systems. To improve the quality of this controller, a reduced-order controller should, therefore, be put in place to simplify the implementation, reduce the configuration of the system but still meet the system requirements for sustainable stability.

\subsection{Design of Reduced Order Balancing Control of Bicyrobo System}

In this section, the $H_{\infty}$ controllers are defined as full order Eq. (34). Implementation of reduced-order H-infinity controllers as third-order ROC designs is proposed and compared with other well-known controllers described in the literature survey. In this higher-order controller, the proposed method reduced to a ROC. The researchers examined and simulated the excessive response of the $\mathrm{HOC}$ and $\mathrm{ROC}$. time response of bicyrobo using different ROCs is shown in Figure 4.

As a result of the reduction of the order in accordance with Figure 4. It can be seen that the response of the fifth, fourth-order reduction controller has an accurate approximation compared to the response of the HOC; the response of the third-order ROC has very small variations; the response of the second and first order.

In addition, Table 4 shows the time response of the HOC to the third order ROC without bicyrobo and has also been compared with the ROC obtained by different

\begin{tabular}{|c|c|c|c|c|c|c|c|}
\hline $\begin{array}{l}\text { Author by design } \\
\text { controllers }\end{array}$ & $\begin{array}{l}\text { Methods for the } \\
\text { reduced controller }\end{array}$ & $\begin{array}{l}\text { Rise Time } \\
\text { (s) }\end{array}$ & $\begin{array}{l}\text { Settling Time } \\
(\mathrm{s})\end{array}$ & $\begin{array}{l}\text { Overshoot } \\
\text { (s) }\end{array}$ & ISE & IAE & ITAE \\
\hline $\begin{array}{l}6^{\text {th }} \text { order controller by } \\
\text { (Bui et al.,2008, 2010) }\end{array}$ & $\begin{array}{l}\text { Particle Swarm } \\
\text { Optimization } \\
\text { (PSO), Genetic } \\
\text { Algorithm (GA) }\end{array}$ & 0.2810 & $\mathrm{NaN}$ & 10.1376 & --- & ---- & --- \\
\hline $\begin{array}{l}3^{r d} \text { order controller by } \\
\text { proposed }\end{array}$ & BSPA & 0.2686 & 0.9138 & 15.4310 & 0.01259 & 0.3119 & 1.504 \\
\hline $\begin{array}{l}3^{\text {rd }} \text { order controller by } \\
\text { A. Sikander et al., } \\
(2019)\end{array}$ & $\begin{array}{l}\text { Cuckoo search } \\
\text { algorithm (CSA) }\end{array}$ & 0.2706 & 0.9056 & 15.2120 & 2.047 & 3.865 & 24.97 \\
\hline $\begin{array}{l}3^{r d} \text { order controller by } \\
\text { (Huu } \text { et al., 2013) }\end{array}$ & Schur analysis (SA) & 0.2673 & 0.9138 & 15.4436 & 7.32 & 7.655 & 49.23 \\
\hline $\begin{array}{l}3^{r d} \text { order controller by } \\
\text { (Liu et al., (1989) and } \\
\text { R. Pinnau, (2008) }\end{array}$ & $\begin{array}{l}\text { Model truncation } \\
\text { (MT) }\end{array}$ & 0.2783 & 0.8641 & 14.0878 & 7.808 & 8.026 & 47.72 \\
\hline $\begin{array}{l}3^{\text {rd }} \text { order controller by } \\
\text { D.K. Sambariya et al., } \\
(2019)\end{array}$ & $\begin{array}{l}\text { Stability Equation } \\
\text { Method (SEM) }\end{array}$ & 0.2052 & 6.6709 & 0 & 19.93 & 3.466 & 1.575 \\
\hline $\begin{array}{l}3^{\text {rd }} \text { order controller by } \\
\text { A. Varga et al., (1993) }\end{array}$ & $\begin{array}{l}\text { Balanced stochastic } \\
\text { model truncation } \\
\text { (BST) }\end{array}$ & 0.2686 & 0.9139 & 15.4435 & 7.33 & 7.654 & 49.23 \\
\hline
\end{tabular}
methods as found in the type of literature search.

Table 4: Response comparison of HOC with ROC of without bicyrobo 
Performance comparison based on time-domain characteristics and performance indices for error calculation is shown in Table 4. It is understood that the response of the reduced controller approximates the results of the HOC very closely with no steady-state error in the response time and precisely matches the response time. So, in this work, I'm trying to implement a third-order ROC for balancing the bicyrobo system.

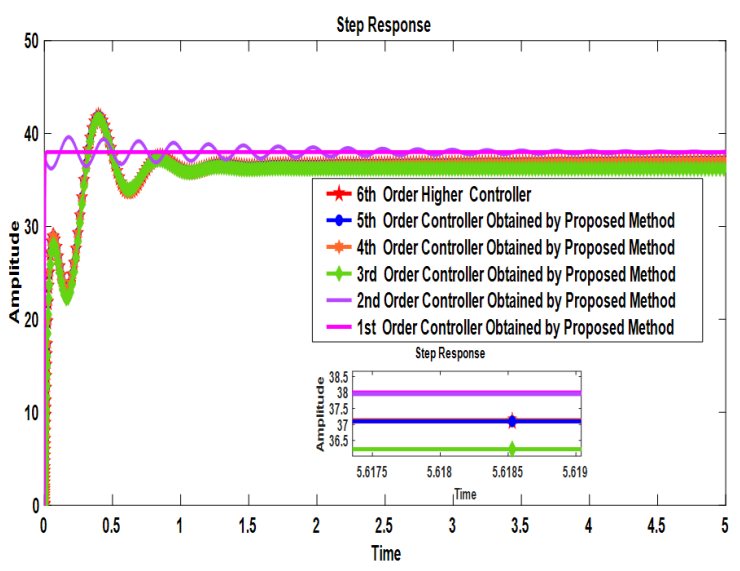

Figure 4: Time response of original and different reduced order controllers by proposed method without bicyrobo

\subsection{Implementation of 3rd order Reduced Controller}

After applying the proposed method focused on the hybridization of BT and SPA, the third-order ROC is as follows:

The ROC in third order obtained by the proposed approach is expressed as :

$$
T_{C r_{-} P}(s)=\frac{1.757 \mathrm{~s}^{3}+1107 \mathrm{~s}^{2}+921.7 \mathrm{~s}+1.719 \mathrm{e} 05}{\mathrm{~s}^{3}+28.01 \mathrm{~s}^{2}+395.9 \mathrm{~s}+4525}
$$

whereas third-order ROC developed by several researchers recommended. The following transfer functions are defined by various suggested methods, respectively. whereas, the ROC in third-order obtained by the method based upon balanced stochastic truncation (BST), A. Varga et al.,(1993) [65] is as follows

$$
T_{C_{-}{ }_{-} B S T}(s)=\frac{1275 \mathrm{~s}^{2}+234.6 \mathrm{~s}+1.993 \mathrm{e} 05}{\mathrm{~s}^{3}+33.78 \mathrm{~s}^{2}+395.1 \mathrm{~s}+5503}
$$

A. Sikander et al., (2019) also recommended a cuckoo search algorithm (CSA) to obtain a ROC in third order for the above sixth-order $\mathrm{H}$ infinity $\mathrm{HOC}$ which is based upon by diminishing the performance indices error using a cuckoo search algorithm. The transfer function of the ROC is given by.

$$
T_{C r_{-} C A S}(s)=\frac{1241 \mathrm{~s}^{2}+234.8 \mathrm{~s}+1.936 \mathrm{e} 05}{\mathrm{~s}^{3}+32.47 \mathrm{~s}^{2}+395 \mathrm{~s}+5274}
$$

The following ROC in third-order is obtained by using the thought of the MOR based on Schur Analysis (SA) method referred to by (Huu et al., 2013) [19].

$$
T_{C r_{-} S A}(s)=\frac{1275 \mathrm{~s}^{2}+234.8 \mathrm{~s}+1.993 \mathrm{e} 05}{\mathrm{~s}^{3}+33.78 \mathrm{~s}^{2}+395.1 \mathrm{~s}+5506}
$$

Furthermore, also ROC design based on reduced order method using stability equation method (SEM) D. Sambariya et al., (2019) and reduced controller using Modal Truncation (MT) [51] suggested by Liu et al., (1989) and R. Pinnau, (2008) [66] are represented by in form of transfer function expressed as:

$$
\begin{array}{r}
T_{C r_{-} S E M}(s)=\frac{1.359 \mathrm{e} 08 \mathrm{~s}^{2}+2.435 \mathrm{e} 07 \mathrm{~s}+1.091 \mathrm{e} 06}{278900 \mathrm{~s}^{3}+3.802 \mathrm{e} 06 \mathrm{~s}^{2}+651900 \mathrm{~s}+28720} \\
T_{C r_{-} M T}(s)=\frac{1057 \mathrm{~s}^{2}+226.50 \mathrm{~s}+1.638 \mathrm{e} 05}{\mathrm{~s}^{3}+27.99 \mathrm{~s}^{2}+395.90 \mathrm{~s}+4521}
\end{array}
$$

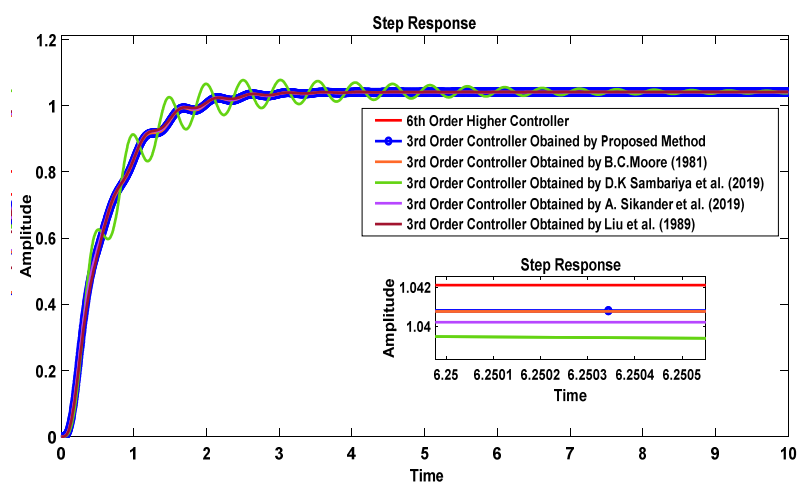

(a)

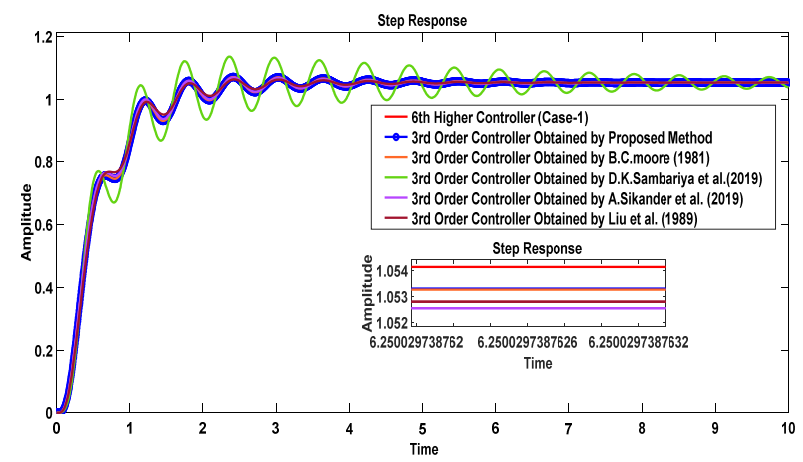

(b)

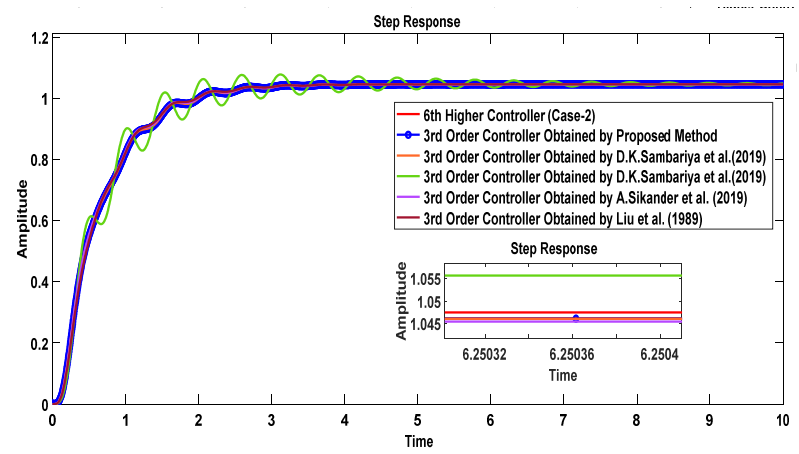

(c)

Figure 5. Time response of original and reduced third order controllers (a) with bicyrobo (b) with bicyrobo (Case-1) (c) with bicyrobo (Case-2)

Tables 5 to 7 show a comparison of ROCs in terms of error indices, and it is clear that the proposed ROC has the lowest values of these error indices. Furt-hermore, to demonstrate the effectiveness of the proposed controller, its behaviour is examined in two different perturbed bicyrobo cases, as previously discussed. Figures 5(a) to (d) show the performance of perturbed bicyrobo with full and reduced order controllers in cases 1 and 2, respectively. 


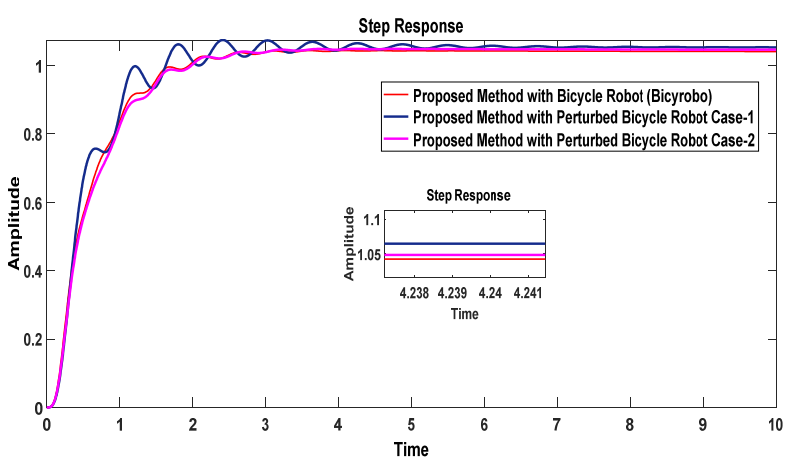

Figure 6. Time response of bicyrobo with reduced third order controllers

Table 5: Performance comparison of closed-loop bicyrobo using third-order controllers

\begin{tabular}{llccc}
\hline $\begin{array}{c}\text { Authors by } \\
\text { design } \\
3^{\text {rd }} \text { order } \\
\text { controller }\end{array}$ & $\begin{array}{c}\text { Methods } \\
\text { for the } \\
\text { reduced } \\
\text { controller }\end{array}$ & ISE & IAE & ITAE \\
\hline $\begin{array}{l}\text { Proposed } \\
\text { Method }\end{array}$ & BSPA & $1.183 \mathrm{e}-06$ & 0.002475 & 0.007867 \\
$\begin{array}{l}\text { A. Sikander } \\
\text { et al., (2019) } \\
\text { (Huu et al., }\end{array}$ & SA & $5.081 \mathrm{e}-05$ & 0.01936 & 0.08185 \\
$\begin{array}{l}\text { 2013) } \\
\text { (Liu et al., }\end{array}$ & MT & $3.169 \mathrm{e}-05$ & 0.01498 & 0.05845 \\
$\begin{array}{l}\text { (1989) and } \\
\text { R. Pinnau, } \\
\text { (2008) }\end{array}$ & & 0.0001763 & 0.02165 & 0.05801 \\
$\begin{array}{l}\text { D.K. } \\
\text { Sambariya } \\
\text { et al., (2019) }\end{array}$ & SEM & 0.007725 & 0.1852 & 0.5091 \\
$\begin{array}{l}\text { A. Varga et } \\
\text { al., (1993) }\end{array}$ & BST & $3.169 \mathrm{e}-05$ & 0.01498 & 0.05845 \\
$\begin{array}{l}\text { (B.C. } \\
\begin{array}{l}\text { Moore, } \\
\text { 1981) and }\end{array}\end{array}$ & BT & $3.077 \mathrm{e}-05$ & 0.01475 & 0.05936 \\
$\begin{array}{l}\text { S.K suman } \\
\text { et al., (2019) }\end{array}$ & & & & \\
\hline
\end{tabular}

Figure 5(a) shows the closed-loop time response of the $\mathrm{HOC}$ with the third in ROC with bicyrobo and also it has been compared with ROC obtained by different methods as found in the works of literature. The same has been performance comparison based on performance index error calculation is depicted in Table 5. It is understood that the response of ROC approximates the results of the HOC very closely with no steady-state error in time response and exactly matches in response.

To illustrate the strength of the proposed controller, the action is studied in two different cases of perturbed bicyrobo, as described above section 4.2, with the HOC and the third-order ROCs for case- 1 and case- 2 shown in Figure 5(b) and Figure 5(c) well, respectively. It is observed that the proposed control strategy often shows outstanding efficiency and efficacy for disturbed bicyrobo comparison to other renowned controllers via the published research. Also compared with a results comparison of closed-loop bicyrobo using third-order ROCs by ascertain-mathematically (compute) of performance indices error to measure the accuracy of the controllers. It is also seen that the proposed controller compared with ISE, IAE, ITAE is much lesser than other controllers depicted in Table 6 is for case 1, and Table 7 is for case 2. Figure 5(b) and 5(c) shown close-loop time response of proposed controller with bicyrobo with perturbed bicyrobo case- 1 and with perturbed bicyrobo case-2. Furthermore, in terms of time response specifications and performance indices, Figure 6 depicts a performance comparison of closed loop bicyrobo using third order controllers. It is also clear from this picture that the closed loop step response of the bicyrobo with the proposed third order controller is significantly better with perturbed in both situations. So, we can say the reduced controller is more efficient and easier than HOC. This way by minimizing the cost and compu-tational time implementation of the controller and reduced the hardware complexity.

Table 6: Performance comparison of closed-loop bicyrobo using third order controllers with Case -1

\begin{tabular}{|c|c|c|c|c|}
\hline $\begin{array}{c}\text { Authors by } \\
\text { design } \\
3^{\text {rd }} \text { order } \\
\text { controller }\end{array}$ & $\begin{array}{l}\text { Methods } \\
\text { for the } \\
\text { reduced } \\
\text { controller }\end{array}$ & ISE & IAE & ITAE \\
\hline $\begin{array}{l}\text { Proposed } \\
\text { Method }\end{array}$ & BSPA & $1.329 \mathrm{e}-06$ & 0.00249 & 0.007835 \\
\hline $\begin{array}{l}\text { A. Sikander } \\
\text { et al., } \\
(2019)\end{array}$ & CSA & $5.582 \mathrm{e}-05$ & 0.01846 & 0.07042 \\
\hline $\begin{array}{l}\text { (Huu et al., } \\
\text { 2013) }\end{array}$ & SA & $2.4 \mathrm{e}-05$ & 0.01235 & 0.04408 \\
\hline $\begin{array}{l}\text { (Liu et al., } \\
\text { (1989) and } \\
\text { R. Pinnau, } \\
\text { (2008) }\end{array}$ & MT & 0.0004686 & 0.03978 & 0.08863 \\
\hline $\begin{array}{l}\text { D.K. } \\
\text { Sambariya } \\
\text { et al., } \\
(2019)\end{array}$ & SEM & 0.01213 & 0.2885 & 1.14 \\
\hline $\begin{array}{l}\text { A. Varga et } \\
\text { al., (1993) }\end{array}$ & BST & $2.4 \mathrm{e}-05$ & 0.01235 & 0.04408 \\
\hline $\begin{array}{l}\text { (B.C. } \\
\text { Moore, } \\
\text { 1981) and } \\
\text { S.K Suman } \\
\text { et al., } \\
(2019)\end{array}$ & BT & $2.329 \mathrm{e}-05$ & 0.01211 & 0.04434 \\
\hline
\end{tabular}

Table 7: Performance comparison of closed-loop bicyrobo using third order controllers with Case -2

\begin{tabular}{lcccc}
\hline $\begin{array}{l}\text { Authors by } \\
\text { design } 3^{\text {rd }} \\
\text { order } \\
\text { controller }\end{array}$ & $\begin{array}{c}\text { Methods } \\
\text { for the } \\
\text { reduced } \\
\text { controller }\end{array}$ & ISE & IAE & ITAE \\
\hline $\begin{array}{l}\text { Proposed } \\
\text { Method }\end{array}$ & BSPA & $1.212 \mathrm{e}-06$ & 0.002394 & 0.006864 \\
$\begin{array}{l}\text { A. } \\
\text { Sikander et } \\
\text { al., (2019) }\end{array}$ & CSA & $5.435 \mathrm{e}-05$ & 0.02021 & 0.08662 \\
(Huu et & SA & $3.475 \mathrm{e}-05$ & 0.01559 & 0.06073 \\
$\begin{array}{l}\text { al., 2013) } \\
\text { (Liu et al., }\end{array}$ & MT & 0.000175 & 0.02197 & 0.05948 \\
$\begin{array}{l}\text { (1989) and } \\
\text { R. Pinnau, } \\
\text { (2008) }\end{array}$ & & & & \\
$\begin{array}{l}\text { D.K. } \\
\text { Sambariya } \\
\text { et al., } \\
\text { (2019) }\end{array}$ & SEM & 0.005949 & 0.1642 & 0.4548 \\
A. Varga & BST & $3.475 \mathrm{e}-05$ & 0.01559 & 0.06073
\end{tabular}


et al.,

(1993)

B.C.

Moore,

1981) and

S.K Suman

et al.,

(2019)

It is also clear and confirmed that all of the results in the form of Tables and Figures of bicyrobo with proposed third ROC are improved and superior to other controllers reported via published research.

\section{CONCLUSION AND FUTURE SCOPE}

The concept of reduced-order modelling has been successfully implemented to design a pre-specified controller structure for bicyrobo balancing control. The five controllers have been designed in the order from first to fifth. To obtain the unknown parameters of the proposed ROCs, the BSPA method has been employed. The ROCs are constructed using the BSPA method and are used to achieve the proposed optimal third-order ROC with identical characteristics to the six order $\mathrm{H} \infty$, HOC. The performance of the controllers proposed / designed is assessed in terms of time-domain response analysis and performance indices error. The study of two separate cases of disturbed bicyrobo system with too many sources of uncertainty such as un-model dynamics, parameter variations and external disturbances is also considered to analyse the robustness, effectiveness, and power of the reduced controller. The efficiency of the proposed controllers is compared with newly established controllers such as $\mathrm{H} \infty$ controller, PID controller-based based on optimization such as GA, PSO and also, MOR based on a reduced controller such as Schur analysis, CSA and modal truncation, etc. An interesting fact has been observed, which is, when third order reduced controllers are employed, that they perform quite well for normal operations, as well as in cir-cum-stances with parameters uncertainty. The discussion here is only about the simulation results. The proposed method provides far superior results which are justified by the compromise of the higher order of the $\mathrm{H} \infty$ controller for typical examples of published work. This approach is more effective when applied successfully to a higher-order system. We can say that the ROC is more efficient and useful than HOC. This way, it is useful for hardware design of controller for any system, which forms the course of the future work, by minimising the cost and computational time for the real-time implementation of the controller.

\section{REFERENCES}

[1] M. Mitić, Z. Miljković, and B. Babić, "Empirical control system development for intelligent mobile robot based on the elements of the reinforcement machine learning and axiomatic design theory," FME Trans., vol. 39, no. 1, pp. 1-8, 2011.

[2] M. Lazarević, "Optimal control of redundant robots in human-like fashion," FME Trans., vol. 33, no. 2, pp. 53-64, 2005.
[3] Z. Miljković and B. Babić, "Empirical control strategy for learning industrial robot," FME Trans., vol. 35, no. 1, pp. 1-8, 2007.

[4] P. Mandić and M. Lazarević, "An application example of webots in solving control tasks of robotic system," FME Trans., vol. 41, no. 2, pp. 153-162, 2013.

[5] P. Y. Lam and T. K. Sin, "Gyroscopic stabilization of a self-balancing robot bicycle," Int. J. Autom. Technol., vol. 5, no. 6, pp. 916-923, 2011.

[6] P. Y. Lam, "Gyroscopic stabilization of a kid-size bicycle," in Proceedings of the 2011 IEEE 5th International Conference on Cybernetics and Intelligent Systems, CIS 2011, 2011, pp. 247-252.

[7] H. Yetkin, S. Kalouche, M. Vernier, G. Colvin, K. Redmill, and U. Ozguner, "Gyroscopic stabilization of an unmanned bicycle," in Proceedings of the American Control Conference, 2014, pp. 45494554.

[8] A. V. Beznos et al., "Control of autonomous motion of two-wheel bicycle with gyroscopic stabilisation," in Proceedings - IEEE International Conference on Robotics and Automation, 1998, pp. 2670-2675.

[9] Y. Tanaka and T. Murakami, "Self sustaining bicycle robot with steering controller," in International Workshop on Advanced Motion Control, AMC, 2004, pp. 193-197.

[10]A. Suebsomran, "Dynamic compensation and control of a bicycle robot," in 2014 International Electrical Engineering Congress, iEECON 2014, 2014, pp. 1-4.

[11] W. Deng, S. Moore, J. Bush, M. Mabey, and W. Zhang, "Towards automated bicycles: Achieving self-balance using steering control," in ASME 2018 Dynamic Systems and Control Conference, DSCC 2018, 2018, pp. 1-9.

[12] Y. Yavin, "Stabilization and control of the motion of an autonomous bicycle by using a rotor for the tilting moment," Comput. Methods Appl. Mech. Eng., vol. 178, no. (3-4), pp. 233-243., 1999.

[13] S. Lee and W. Ham, "Self stabilizing strategy in tracking control of unmanned electric bicycle with mass balance," in IEEE International Conference on Intelligent Robots and Systems, 2002, pp. 22002205.

[14]P. P. Khargonekar and M. A. Rotea, "Mixed H2 /Hळ Control: A Convex Optimization Approach," IEEE Trans. Automat. Contr., vol. 36, no. 7, pp. 824-837, 1991.

[15]D. S. Bernstein and W. M. Haddad, "LQG Control with an HœPerformance Bound: A Riccati Equation Approach," IEEE Trans. Automat. Contr., vol. 34, no. 3, pp. 293-305, 1989.

[16]B. T. Thanh and M. Parnichkun, "Balancing control of bicyrobo by particle swarm optimization-based structure-specified mixed $\mathrm{H} 2 / \mathrm{H} \infty$ control," Int. J. Adv. Robot. Syst., vol. 5, no. 4, pp. 395-402, 2008.

[17] T. T. Bui, M. Parnichkun, and C. H. Le, "Structure- 
specified Hळ loop shaping control for balancing of bicycle robots: A particle swarm optimization approach," Proc. Inst. Mech. Eng. Part I J. Syst. Control Eng., vol. 224, no. 7, pp. 857-867, 2010.

[18] B. Sen Chen, Y. M. Cheng, and C. H. Lee, “A Genetic Approach to Mixed H2/Hळ Optimal PID Control," IEEE Control Syst., vol. 15, no. 5, pp. 51-60, 1995.

[19] C. N. Huu, K. N. Vu, D. H. Dao, and T. B. Trung, "Researching model order reduction based on Schur analysis," in Proceedings of the 2013 IEEE Conference on Cybernetics and Intelligent Systems, CIS 2013, 2013, pp. 60-65.

[20]A. Sikander and R. Prasad, "Reduced order modelling based control of two wheeled mobile robot," J. Intell. Manuf., vol. 30, no. 3, pp. 1057 1067, 2019.

[21] H. S. Yamada and K. S. Ikeda, “A Numerical Test of Padé Approximation for Some Functions with Singularity," Int. J. Comput. Math., vol. 11, pp. 117, 2014.

[22] C. B. Vishwakarma and R. Prasad, "Time domain model order reduction using Hankel matrix approach," J. Franklin Inst., vol. 351, no. 6, pp. 3445-3456, 2014.

[23]D. Sambariya and G. Arvind, "High Order Diminution of LTI System Using Stability Equation Method," Br. J. Math. Comput. Sci., vol. 13, no. 5, pp. 1-15, 2016.

[24]A. K. Prajapati and R. Prasad, "A New Model Reduction Method for the Linear Dynamic Systems and Its Application for the Design of Compensator," Circuits, Syst. Signal Process., pp. 1-21, 2019.

[25] S. K. Suman and A. Kumar, "Higher-Order Reduction of Linear System and Design of Controller," Sci. J. King Faisal Univ., vol. 2020, no. 3, pp. 1-16, 2020.

[26]S. K. Suman, "Reduction of Large-Scale Dynamical Systems by Extended Balanced Singular Perturbation Approximation," Int. J. Math. Eng. Manag. Sci., vol. 5, no. 5, pp. 939-956, 2020.

[27]A. C. Antoulas, Approximation of Large-Scale Dynamical Systems. Society for Industrial and Applied Mathematics, Philadelphia, PA, 2005.

[28]K. Zhou, G. Salomon, and E. Wu, "Balanced realization and model reduction for unstable systems," Int. J. Robust Nonlinear Control, vol. 9, no. 3, pp. 183-198, 1999.

[29] B. C. Moore, "Principal Component Analysis in Linear Systems: Controllability, Observability, and Model Reduction," IEEE Trans. Automat. Contr., vol. 26, no. 1, pp. 17-32, 1981.

[30]B. N. Datta, Systems and Control in the TwentyFirst Century. Birkhäuser, Boston, MA, 2003.

[31]J. Hahn and T. F. Edgar, "Balancing approach to minimal realization and model reduction of stable nonlinear systems," Ind. Eng. Chem. Res., vol. 41, no. 9, pp. 2204-2212, 2002.
[32]A. Suebsomran, "Balancing control of bicycle robot," in Proceedings - 2012 IEEE International Conference on Cyber Technology in Automation, Control, and Intelligent Systems, CYBER 2012, 2012, pp. 69-73.

[33] C. F. Huang, Y. C. Tung, and T. J. Yeh, "Balancing control of a robot bicycle with uncertain center of gravity," in Proceedings - IEEE International Conference on Robotics and Automation, 2017, pp. 5858-5863.

[34] A. L. Schwab, P. D. L. De Lange, R. Happee, and J. $\mathrm{K}$. Moore, "Rider control identification in bicycling using lateral force perturbation tests," Proc. Inst. Mech. Eng. Part K J. Multi-body Dyn., vol. 227, no. 4, pp. 390-406, 2013.

[35] T. Kawamura and T. Murakami, "Robust stabilization control for an electric bicycle," Electr. Eng. Japan (English Transl. Denki Gakkai Ronbunshi), vol. 132, no. 6, pp. 651-658, 2014.

[36] K. Iuchi, H. Niki, and T. Murakami, "Attitude control of bicycle motion by steering angle and variable COG control," in IECON Proceedings (Industrial Electronics Conference), 2005, pp. 2065-2070.

[37]F. Grasser, A. D’Arrigo, S. Colombi, and A. C. Rufer, "JOE: A mobile, inverted pendulum," IEEE Trans. Ind. Electron., vol. 49, no. 1, pp. 107-114, 2002.

[38] Y. S. Ha and S. Yuta, "Trajectory tracking control for navigation of the inverse pendulum type selfcontained mobile robot," Rob. Auton. Syst., vol. 17, no. 1-2, pp. 65-80, 1996.

[39]L. J. Butler and G. Bright, "Feedback control of a self-balancing materials handling robot," in 2008 10th International Conference on Control, Automation, Robotics and Vision, ICARCV 2008, 2008, pp. 274-278.

[40] S. Raja, S. Ram, and D. Dinesh Kumar, "Designing of Optimization Techniques based PID controller for Self Balancing Bicycle," Int. J. Adv. Comput. Electron. Eng., vol. 2, no. 6, pp. 21-25, 2017.

[41] A. C. Antoulas, P. Benner, and L. Feng, "Model reduction by iterative error system approximation," Math. Comput. Model. Dyn. Syst., vol. 42, no. 2, pp. 103-118, 2018.

[42] A. C. Antoulas, D. C. Sorensen, and Y. Zhou, "On the decay rate of Hankel singular values and related issues," Syst. Control Lett., vol. 46, no. 5, pp. 323342, 2002.

[43] M. Yasuda, "Spectral characterizations for hermitian centrosymmetric K-matrices and hermitian skew-centrosymmetric K-matrices," SIAM J. Matrix Anal. Appl., vol. 25, no. 3, pp. 601605, 2004.

[44] "Model Order Reduction of Transmission Line Model," WSEAS Trans. CIRCUITS Syst., vol. 19, no. 7, pp. 62-68, Feb. 2020.

[45] M. M. Uddin, A. Mathematics, M. Gutachter, P. B. Prof, and M. Heinkenschloss, "Computational 
Methods for Model Reduction of Large-Scale Sparse Structured Descriptor Systems," 2015.

[46] V. Sreeram and P. Agathoklis, "Model reduction using balanced realizations with improved low frequency behaviour," Syst. Control Lett., vol. 12, no. 1, pp. 33-38, 1989.

[47] S. K. Singh and S. K. Nagar, "BSPA based H 2/H $\infty$ controller reduction," in Proceedings of the IEEE INDICON 2004 - 1st India Annual Conference, 2004, pp. 195-198.

[48] S. Gugercin, “An iterative SVD-Krylov based method for model reduction of large-scale dynamical systems," Linear Algebra Appl., vol. 428, no. 9, pp. 1964-1986, 2008.

[49]M. Imran, A. Ghafoor, and V. Sreeram, “A frequency weighted model order reduction technique and error bounds," Automatica, vol. 50, no. 12, pp. 3304-3309, 2014.

[50] M. G. Safonov and R. Y. Chiang, "A Schur Method for Balanced-Truncation Model Reduction," IEEE Trans. Automat. Contr., vol. 34, no. 7, pp. 729-733, 1989.

[51] Y. Liu and B. D. O. Anderson, "Singular perturbation approximation of balanced systems," Int. J. Control, vol. 50, no. 4, pp. 1379-1405, 1989.

[52]D. Škatarić and N. R. Kovačević, "The system order reduction via balancing in view of the method of singular perturbation," FME Trans., vol. 38, no. 4, pp. 181-187, 2010.

[53] D. Kumar, J. P. Tiwari, and S. K. Nagar, "Reducing order of large-scale systems by extended balanced singular perturbation approximation," Int. J. Autom. Control, vol. 6, no. 1, pp. 21-38, 2012.

[54] P. V. Kokotovic, R. E. O’Malley, and P. Sannuti, "Singular perturbations and order reduction in control theory - An overview," Automatica, vol. 12, no. 2, pp. 123-132, 1976.

[55]D. W. Gu, P. H. Petkov, and M. M. Konstantinov, "Lower-order controllers," in Advanced Textbooks in Control and Signal Processing, Springer, London, 2013, pp. 73-91.

[56]C. Guiver, "The generalised singular perturbation approximation for bounded real and positive real control systems," Math. Control Relat. Fields, vol. 9, no. 2, pp. 313-350, 2019.

\section{ACRONYMS}

$\begin{array}{ll}\text { Bicyrobo } & \text {-Bicycle Robot } \\ \text { BSPA } & \text {-Balanced Singular Perturbation } \\ & \begin{array}{l}\text { Approximation } \\ \text { BST }\end{array} \\ \text {-Balanced Stochastic Truncation } \\ \text { CADO } & \text {-Balancd Truncation } \\ \text { CMG } & \text {-Camber Angle Disturbance Observer } \\ \text { COG } & \text {-Control Moment Gyroscope } \\ \text { CSA } & \text {-Centre of Gravity } \\ \text { DR } & \text {-Direct Reduction } \\ \text { DT } & \text {-Direct Truncation } \\ \text { EMF } & \text {-Electromotive force } \\ \text { GA } & \text {-Genetic Algorithm }\end{array}$

[57] C. B. Vishwakarma and R. Prasad, "MIMO System Reduction Using Modified Pole Clustering and Genetic Algorithm," Model. Simul. Eng., vol. 2009, pp. 1-5, 2009.

[58]A. Sikander and R. Prasad, "Linear time-invariant system reduction using a mixed methods approach," Appl. Math. Model., vol. 39, no. 16, pp. 4848-4858, 2015.

[59] G. Parmar, S. Mukherjee, and R. Prasad, "System reduction using factor division algorithm and eigen spectrum analysis," Appl. Math. Model., vol. 31, no. 11, pp. 2542-2552, 2007.

[60]A. Narwal and B. R. Prasad, "A novel order reduction approach for LTI systems using cuckoo search optimization and stability equation," IETE J. Res., vol. 62, no. 2, pp. 154-163, 2016.

[61]A. Sikander and P. Thakur, "Reduced order modelling of linear time-invariant system using modified cuckoo search algorithm," Soft Comput., vol. 22, no. 10, pp. 3449-3459, 2018.

[62]A. Sikander, P. Thakur, and I. Uniyal, "Hybrid method of reduced order modelling for LTI system using evolutionary algorithm," in Proceedings on 2016 2nd International Conference on Next Generation Computing Technologies, NGCT 2016, 2017, pp. 84-88.

[63]A. Sikander and R. Prasad, "Soft Computing Approach for Model Order Reduction of Linear Time Invariant Systems," Circuits, Syst. Signal Process., vol. 34, no. 11, pp. 3471-3487, 2015.

[64]A. Sikander, P. Thakur, R. C. Bansal, and S. Rajasekar, "A novel technique to design cuckoo search based FOPID controller for AVR in power systems," Comput. Electr. Eng., vol. 70, pp. 261274, 2018.

[65]A. Varga and K. H. Fasol, "A New Square-root Balancing-Free Stochastic Truncation Model Reduction Algorithm," IFAC Proc. Vol., vol. 26, no. 2, pp. 469-472, 1993.

[66]R. Pinnau, "Model Reduction via Proper Orthogonal Decomposition," in Model Order Reduction: Theory, Research Aspects and Applications, Springer, Berlin, Heidelberg, 2008, pp. 95-109.

$\begin{array}{ll}\text { HOC } & \text {-Higher Order Controller } \\ \text { HSV } & \text {-Hankel Singular value } \\ \text { IAE } & \text {-Integral Absolute Error } \\ \text { ISE } & \text {-Integral Square Error } \\ \text { ITAE } & \text {-Integral Time-Weighted Absolute Error } \\ \text { LQR } & \text {-Linear Quadratic Regulator } \\ \text { LTI } & \text {-Linear Time Invarient } \\ \text { MI } & \text {-Moment of Ineria } \\ \text { MOR } & \text {-Model Order Reduction } \\ \text { MT } & \text {-Model truncation } \\ \text { PD } & \text {-Propotional Derivative } \\ \text { PID } & \text {-Propotional Integral Derivative } \\ \text { PSO } & \text {-Particle Swarm Optimization }\end{array}$


ROC -Reduced Order Controller

ROM -Reduced Order Modelling

SA $\quad$-Schur analysis

SEM -Stability Equation Method

\section{МОДЕЛИРАЊЕ СМАҢЕНОГ РЕДА И КОНТРОЛА БАЛАНСИРАҢА БИЦИКЛИСТИЧКОГ РОБОТА}

\section{С.К. Суман, А. Кумар}

Приказују се резултати истраживања контроле балансирања бициклистичког робота применом моделирања смањеног реда претходно дизајнираног контролера вишег реда да би се извео редуковани контролер. Бициклистички робот који је нестационаран систем а који прате други узроци неизвесности, као што је динамика без модела, параметри одступања и спољашњи поремећаји, представља предмет интересовања истраживача. У литератури се појављују контролери вишег реда (НОC), цео систем је комплексан с аспекта анализе, синтезе, унапређења и има хардвер чија је примена отежана. Зато је у раду развијен контролер редукованог реда (ROC) који успешно савладава непредвидљиву динамику. ROC je дизајниран применом метода редукције модела (MOR) који је
SISO -Single Input Single Output

SMC -Sliding Mode Controller

SPA -Singular Perturbation Approximation

резултат хибридизације приступа уравнотеженог скраћивања (ВТ) и апроксимације сингуларног поремећаја (SPA). Тако добијени редуковани модел, који задржава DC појачање, се назива приступ апроксимације уравнотеженог сингуларног поремећаја (BSPA). Базира се на очувању доминантних режима (стања) система као и на елиминисању стања са релативно безначајним карактеристичним својствима. Недостатак ВТ метода је тај што за модел смањеног реда, вредности стационарног стања или DC појачања не одговарају тренутним вредностима система. За овај недостатак је одговоран BSPA. У поређењу са постојећим методима овај метод интегрише више доминантних захтева и доприноси бољој апроксимацији. Резултати добијени применом предложеног контролера упоређени су са резултатима добијеним дизајнирањем старијих контролера и објављеним у литератури за исте функције. Нови контролер има боље перформансе него контролер вишег реда. Перформансе НОС и ROC су испитане у временском домену и с аспекта грешке индекса перформанси. 